\title{
THE FINANCIAL FEASIBILITY ANALYSIS FOR CONSTRUCTION PLAN OF FERRO-NICKEL (Fe-Ni) SMELTER PLANT AT SOUTH KONAWE REGENCY, SOUTH EAST SULAWESI
}

\author{
ANALISIS KELAYAKAN FINANSIAL RENCANA PEMBANGUNAN \\ PABRIK PELEBURAN FERRO-NIKEL (Fe-Ni) DI KABUPATEN \\ KONAWE SELATAN, SULAWESI TENGGARA
}

\author{
HART A HARYADI \\ $R$ \& D Centre for Mineral and Coal Technology \\ Jalan Jenderal Sudirman 623 Bandung 40211 \\ Ph. (+6222) 6030483, Fax. (+6222) 6003373 \\ e-mail: hartah@tekmira.esdm.go.id
}

\begin{abstract}
The objective of the study is to comprehend the feasibility for construction plan of smelter plant to process the nickel laterite into ferro-nickel (Fe-Ni). PT. Macika Mineral Industries (PT. MMI), located at Lolowua village South Konawe, Southeast Sulawesi will implement such a plan Law No. 4 of 2009 on Mineral and Coal Mining obliges the mining investors to process the minerals into semi-finished or finished products in the domestic country before selling them abroad. The raw materials for PT. MMI smelter plant will be supplied by PT. Macika Mada Madana (PT. MMM) as one of PT. MMI group members PT. MMI is the holder of Production Operation Mining Permit that covers an area of $705 \mathrm{Ha}$ and is located in Watudemba village, Palangga District and Keono Village, South Palangga District, South Konawe Regency. The mining area of PT. MMI is located $7 \mathrm{~km}$ from the PT. MMM planed plant. The total Ni reserve owned by PT. MMM is $18,930,700$ tons. Of $18,930,700$ ton reserves; $4,390,645$ tons belongs to the measured one performing the average grade of nickel and iron around 1.97 and $23.14 \%$ respectively while around $14,540,055$ tons that contain the average grade of nickel and iron about 1.92 and $23.14 \%$ respectively goes to the inferred reserve. PT. MMI requires 960,000 tons per year of Ni raw material it means that PT. MMM can supply the processing plant up to 20 years. Net present value (NPV), internal rate of return (IRR), return on investment (ROI), payback period (PBP), benefit cost ratio (B / CR), and breakeven point (BEP) are the criteria for evaluating the financial need of PT. MMI. The results showed that the NPV was about US\$726,883,479 while the IRR and the ROI were around $18.00 \%$ and $212.90 \%$ respectively. Calculating the PBP and the B/C achieved 6.19 years and 3.21 correspondingly. The reached BEP was US\$ 754 per ton for the production of 50,504 tons. The analysis showed that the construction of ferronickel (Fe-Ni) plant by PT. MMI was financially acceptable to be. However, using several variable measurements in analyzing the sensitivity of the business, namely by the selling price of ferro-nickel is assumed to be reduced by $5 \%$ and production cost is increased by $5 \%$, the plan is not sensitive to decreasing selling price and increasing production cost.
\end{abstract}

Keywords: financial analysis, feasibility, processing, smelting, ferronickel, value added

\begin{abstract}
ABSTRAK
Tujuan penelitian adalah untuk mengetahui kelayakan usaha rencana pembangunan pabrik peleburan bijih nikel laterit menjadi ferro-nikel (Fe-Ni) yang akan dilaksanakan oleh PT. Macika Mineral Industries (PT. MMI), yang berlokasi di Desa Lolowua, Konawe Selatan, Sulawesi Tenggara. Undang-Undang Nomor 4 Tahun 2009 tentang Pertambangan Mineral dan Batubara mewajibkan investor pertambangan untuk mengolah mineral menjadi produk setengah jadi atau produk jadi di dalam negeri sebelum dijual ke luar negeri. Bahan baku bijih nikel untuk pabrik peleburan PT. MMI ini akan dipasok oleh PT. Macika Mada Madana (PT.MMM) yang merupakan grup PT. MMI selaku pemegang IUP Operasi Produksi seluas
\end{abstract}


705 ha, di Desa Watudemba, Kecamatan Palangga dan Desa Keono, Kecamatan Palangga Selatan, Kabupaten Konawe Selatan. Jarak lokasi IUP adalah $7 \mathrm{~km}$ dari rencana lokasi pabrik. PT.MMM. Sesuai hasil eksplorasi, total cadangan yang dimiliki oleh PT. MMM adalah 18.930.700 ton terdiri atas cadangan terukur sebesar 4.390 .645 ton dengan kadar rata-rata Ni 1,97\% dan Fe 23,14\% dan cadangan terkira 14.540.055 ton dengan kadar rata-rata Ni 1,92\% dan Fe 24,17\%. Kebutuhan bahan baku PT. MMI adalah 960.000 ton per tahun sehingga PT. MMM dapat memasok pabrik pengolahan hingga 20 tahun. Penilaian analisis finansial menggunakan kriteria net present value (NPP), internal rate or return (IRR), return on invesment $(\mathrm{ROI})$, payback period (PBP), benefit cost ratio (B/C R), serta breakeven point (BEP), diperoleh nilai NPV US\$ 726.883.479, IRR 18\%, ROI 212,90\%, PBP 6,19 tahun, B/C sebesar 3,21 dan BEP untuk harga sebesar US\$ 754 per ton dan produksi 50.504 ton. Penilaian analisis menunjukkan pembangunan pabrik komersial peleburan ferro-nikel (Fe-Ni) yang akan dibangun PT. MMI secara finansial layak dijalankan dan proyek dapat diterima. Namun menggunakan beberapa variabel pengukuran dalam menganalisis sensitivitas usaha, yaitu harga jual ferro-nikel (Fe-Ni) diasumsikan diturunkan sebesar 5\% dan biaya produksi dinaikan sebesar 5\%, rencana pembangunan pabrik peleburan ini tidak sensitif terhadap penurunan harga jual dan peningkatan biaya produksi.

Kata kunci: analisis finansial, kelayakan, pengolahan, peleburan, ferronikel, nilai tambah

\section{INTRODUCTION}

South Konawe retains a significant nickel ore resource. However, the resources have not yet provided an optimal economic benefits as the material is sold in the raw material (Permana, 2010). Based on the data from Mining Office of Energy and Mineral Resources South East Sulawesi (Dinas Pertambangan Provinsi Sulawesi Tenggara, 2015), the nickel ores at Southeast province spread into $313.79 \mathrm{Ha}$ performing the resource of 97.40 billion tons (Table 1). Referring to the functions of forest resources, the status of nickel areas at Southeast Sulawesi can be divided into protected and cultivation areas, namely with wide 152.20 thousand and 161.59 thousand hectares respectively.

In line with the national policy mandated by Law No. 4 Year 2009 on Mineral and Coal, and is regulated by the Ministry of EMR Regulation No. 8 in 2015 that obliges all mining permit holders to process and purify the mining products in the country prior to exporting it (Kementerian Perdagangan, 2013). PT. MMI plans to construct a ferronickel (Fe-Ni) processing plant in South Konawe at which the laterite ore is available in such the district. The plant construction is a response of PT. MMl to the government policy in terms of a acquiring the approval to export the nickel in which its grade corresponds to the MEMR Regulation No. 8 year 2015.

Financial analysis needs to be conducted prior to constructing the plant, to determine whether such the plant is feasible or not as well as to find out its benefits and investment capabilities in providing profits to the company. The disconnected link of the nickel value added still weakens the domestic industry-user due to the raw material needs to be imported while the Indonesian nickel resources is significant. The central and the local governments look forward that PT MMI constructs a benefit nickel processing and refining plant at South Konawe Regency. Criteria to evaluate that the plant construction is feasible or not includes net present value (NPV), internal rate of return (IRR), return on investment (ROI), payback period (PBP), benefit cost ratio $(\mathrm{B} / \mathrm{C} \mathrm{R})$ and breakeven point (BEP).

PT.MMI is located in the Lolowua village, Southeast Sulawesi. The plant construction is conducted by Brill Mineral Industries China (BMIC). As the owner of the technology, BMIC will also operate the plant along with PT. MMI. Location of PT MMI is shown in Figure 1.

The raw material for smelter plant comes from PT. MMM as the holder of the Production Operating Mining Permit possessing of $705 \mathrm{Ha}$ and is located in Watudemba village of Palangga District and Keono Village of South Palangga District, South Konawe Regency. The location for Fe-Ni smelter of PT. MMI is planed near the location of PT. MMM mining area. The distance is more or less $7 \mathrm{~km}$ and can be reached from Kendari within \pm 2.5 hours. 


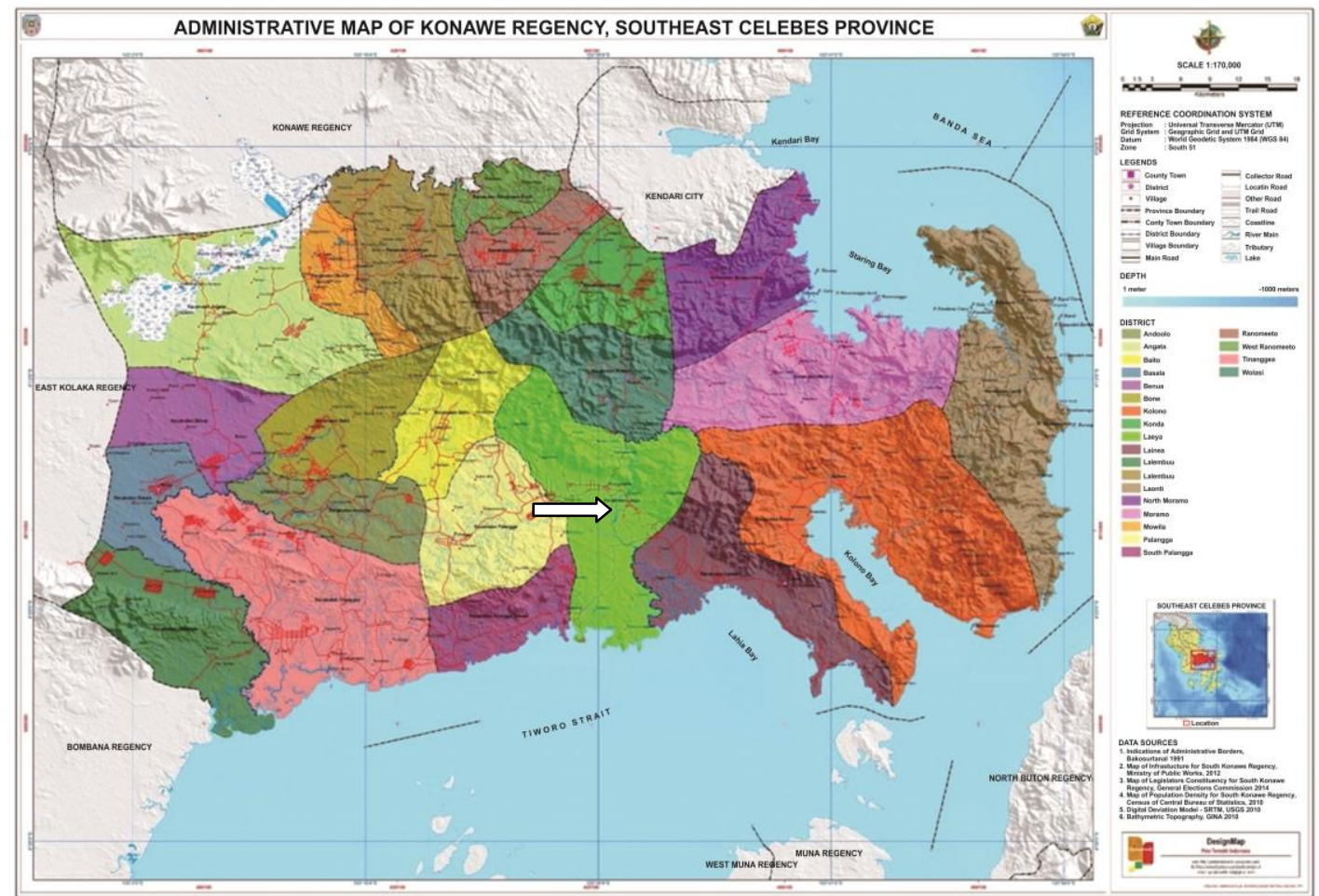

Figure 1. Plant of ferronickel at Palangga, owned by PT MMM (Badan Pusat Statistik Provinsi Sulawesi Tenggara, 2014)

PT. MMM has the measured reserve around 4,390,645 tons performing the average grade of $1.97 \% \mathrm{Ni}$ and $23.14 \% \mathrm{Fe}$ while the inferred reserves is around $14,540,055$ tons showing the average grade of $1.92 \% \mathrm{Ni}$ and $\mathrm{Fe} 24.17 \%$. The total potential of both reserves is reserves 18.9307 million tons and the average grades of $1.93 \%$ and $23.93 \%$ respectively. Two lines of mini blast furnace (MBF) requires 480,000 tons laterite ores per year until the 4th year. From year 5 to 20, the company requires the raw materials of 960,000 tons due to the end of year 4 , the company's furnace will have two additional lines. The total lines will be 4 .

Referring to the 960,000 tons of raw materials PT. MMI will obtain adequate nickel laterite ore supplies to meet the needs of the processing and purification/smelter plant for more than 20 years of production period. Total reserves of PT. MMM will likely be added, it is caused the company will conduct further exploration, and based on data from the Mining Office of South East Sulawesi province, there is a large amount of nickel resources available at South Konawe Regency reached 4.34 billion tons (Table 1).
PT. MMI plans to sell the ferronickel products to the China market. The selling price is based on the formula of nickel selling price at the LME market using a free on board (FOB) system that based on the longterm and the short-term contracts as well as the spot sales. The payment method uses irrevocable letter of credits (LC) and the FOB sales value in the mother vessel. While, for calculating the quality and quantity of such products, the company uses surveyors.

The amount of nickel resource located in Southeast Sulawesi, especially at south Konawe, draw attention of PT. MMI to build a smelter plant at South Konawe. The purpose is to increase the value-added of lateritic nickel ore that have been sold as raw materials. According to Astuti et al. (2012). The laterite nickel ore is usually found in a tropical or sub-tropical area containing high $\mathrm{Fe}$ and Mg-weathered ultramafic rocks. The deposit usually shows the different layers because of weather conditions. The first layer is a silica-rich layer and the second layer is dominated by limonite, goethite [ $\mathrm{FeO}$ $(\mathrm{OH})]$ and hematite $\left(\mathrm{Fe}_{2} \mathrm{O}_{3}\right)$. The third layer is saprolite $\left.\left[(\mathrm{Ni}, \mathrm{Mg}) \mathrm{SiO}_{3} \cdot \mathrm{nH}_{2} \mathrm{O}\right)\right]$ that is rich in magnesium and basal elements while the 
fourth layer is the weathered and unweathered bedrocks. An Mg-rich layer or known as saprolite - $\left[\mathrm{Mg}_{3} \mathrm{Si}_{2} \mathrm{O}_{5}(\mathrm{OH})\right]$ occurs between the saprolite and limonite. Such a layer contains $10-20 \% \mathrm{Mg}$. Musnajam (2012), stated that the nickel laterite belongs to the laterite from ultramafic rock weathering either serpentine or peridotite that are rich in olivine and pyroxene.

Processing the nickel laterite to be the ferronickel aims to separate the valuable minerals from its impurities to get the high value concentrates and worthless tailings (Subagja, Prasetyo and Mayangsari, 2016). The used method by PT. MMI will be smelting method to yield a ferronickel containing $10-12 \%$ Ni. According to Pratama, Sibarani and Puspandaru (2011), there are two types of nickel ores, namely sulfide and oxide ores The sulfide one is mostly used to be processed as processing the oxide one needs a high energy. The low grade of $\mathrm{Ni}(1-2 \%)$ is the cause.

Selecting smelting methods by PT. MMI is based on the nickel ore characteristics. The plant location is near the PT. MMM mining operations. Charcoal usage as the energy to process the ores due to relatively low for investment and production costs. The product is a ferronickel that agrees with the criteria of MEMR Regulation No.8/2015, namely standard-export ferronickel with grade of $\geq 10 \%$ Ni. Mini blast furnace MBF), a technology that is employed by PT. MMI and will be implemented by Brill-China Mineral Industries (BMI). This method is carried out in the mini hot blast furnace or MBF. The produced ferronickel contains 10$12 \% \mathrm{Ni}$. A type of a blast furnace using a charcoal as a fuel and a reductor in the medium and small sizes has been operated in Brazil since several decades. The feeds put into the blast furnace include the iron ore or its agglomerated form, charcoal or cokes and flux materials. The air in the stove is heated at $7.000^{\circ} \mathrm{C}$. The required energy comes from carbon material. Such the materials are also consumed in the reduction process to a perfect condition performing by small $\mathrm{FeO}$ content in the slag or even no $\mathrm{FeO}$ anymore (Kartaman, Al Hasa and Paid, 2013). PT. MMM supplies the ore from its mine area and then is sent to the MBF location, $7 \mathrm{~km}$ from the mine mouth. Due to its high water content, the ores are then dried and heated prior to going to the MBF. The iron- and nickel oxides are reduced to be the iron-nickel alloy slag. The slag is assumed to contain the $\mathrm{Ni}$ and the $\mathrm{S}$ around $9-10 \%$ and $7-9 \%$ respectively. Processing the $-10 \mathrm{~mm}$-slag requires expensive equipment and its result is insignificant. This causes a high cost of $\mathrm{Ni}$ processing. As a result, PT MMI sells the slag to other industries that are interested in processing such a slag.

Table 1. Potency of nickel resources at Southeast Sulawesi

\begin{tabular}{|c|c|c|c|c|c|}
\hline No. & Regencies & $\begin{array}{l}\text { Resources } \\
\text { (Tons) }\end{array}$ & $\begin{array}{c}\text { Total } \\
\text { Production in } \\
\text { Period } \\
2008-2013 \\
\text { (Tons) } \\
\end{array}$ & $\begin{array}{c}\text { Remaining } \\
\text { Resources (Tons) }\end{array}$ & $\begin{array}{c}\text { Element content of } \\
\text { the sample }(\%)\end{array}$ \\
\hline 1 & North Konawe & $46,007,440,652.72$ & $16,249,021.00$ & $45,991,191,631.72$ & $\begin{array}{l}\mathrm{Ni}=1.91-2.4 \% \\
\mathrm{Fe}=14.07-17.47 \%\end{array}$ \\
\hline 2 & Bombana & $28,200,014,800.00$ & $5,335,801.00$ & $28,194,678,999.00$ & - \\
\hline 3 & Kolaka & $12,819,244,028.00$ & $16,071,935.90$ & $12,803,172,092.10$ & $\mathrm{Ni}=2.17 \% ; \mathrm{Fe}=34 \%$ \\
\hline 4 & South Konawe & $4,348,838,160.00$ & $8,007,223.00$ & $4,340,830,937.00$ & $\begin{array}{l}\mathrm{Ni}=2.11-2.13 \% \\
\mathrm{Fe}=21.96-23.03 \%\end{array}$ \\
\hline 5 & North Kolaka & $2,763,796,196.00$ & $6,654,418.29$ & $2,757,141,777.71$ & $\begin{array}{l}\mathrm{Ni}=1.76-1.9 \% \\
\mathrm{Fe}=18.1-20.18 \%\end{array}$ \\
\hline 6 & $\begin{array}{l}\text { Buton dan Kota } \\
\text { Bau-Bau }\end{array}$ & $1,676,332,000.00$ & $2,035,966.00$ & $1,674,296,034.00$ & $\begin{array}{l}\mathrm{Ni}=2-2.07 \% \\
\mathrm{Fe}=20.10-34 \%\end{array}$ \\
\hline 7 & Konawe & $1,585,927,189.00$ & $40,000.00$ & $1,585,887,189.00$ & $\begin{array}{l}\mathrm{Ni}=1.8-2 \% \\
\mathrm{Fe}=18.03-16.25 \%\end{array}$ \\
\hline \multirow[t]{2}{*}{8} & Cross district & & $2,568,344.00$ & & - \\
\hline & Total & $97,401,593,025.72$ & $56,962,709.19$ & $97,344,630,316.53$ & - \\
\hline
\end{tabular}


PT MMI will apply the technology from China when processing the nickel ores. China has succeeded to develop and produce the nickel pig iron (NPI) and the ferronickel (Fe-Ni) in recent years. The goal is to open the market with China as a partner and also as the owner of the technology. Accordingly; for the time being, marketing of such products will go to China and its partner.

Based on the research by Haryadi in 2016, constructing the nickel processing and refining plants will provide a positive economic impacts on the economy of Southeast Sulawesi. However, constructing plants in such a region needs to conduct a financial analysis to determining feasible or not to build the plants (Haryadi, 2013). The purpose to analyze the financial aspects of the feasibility study for constructing ferronickel smelting plant plan of PT. MMI is to determine the investment plan by comparing the expenditure and the revenue, such as fund availability, capital cost, and project ability to repay the funds on specified time (Afandi, 2014). The success of the project is the most important goals for the investors, contractors, and especially the product users (Honesti and Djali, 2012). The parameters used for assessing the financial analysis includes net present value (NPV), internal rate of return (IRR), return on investment $(\mathrm{ROI})$, payback period (PBP), benefit cost ratio ( $\mathrm{B} /$ $\mathrm{CR}$ ) and breakeven point (BEP), (Fahmi, 2011).

A feasible or not feasible project can be evaluated from the efficiency of the usage fees as well as the ratio between the total revenue and the total costs (Khumairoh, 2013). If the project is worth to be conducted, it should refer to $B C R>1$; IRR $>$ the prevailing bank rate; PBP returns < the project life; labor productivity $>$ the prevailing wage rate; income $>$ the business expenses. The loss can be avoided if the company refers to those above items (Baroto and Ariani, 2010). According to (Ermiati, 2011), the most important thing is the product can meet the raw material requirements as needed by industrial users as well as the product can improve value- added economy for the surrounding region (Rusdiana and Martono, 2014).

\section{METHODOLOGY}

PT. Macika Mineral Industries provided the primary data to be analyzed. The supporting data were obtained from the Department of Mines and Energy of the Province of Southeast Sulawesi, the Regional Planning Agency of Southeast Sulawesi province, the Central Bureau of Statistics of Southeast Sulawesi province while the comparative data were derived from various journals, theses and proceedings. The primary data were analyzed using the parameters: NPV, IRR, ROI, PP, B/C, and BEP.

\section{RESULTS DAN DISCUSSION}

The feasibility analysis was conducted only to financial aspects from PT. MMI. Early 2017, the company will develop two MBFs Each MBF retains a capacity of $80 \mathrm{~m}^{3}$ respectively. The MBF products will be 54,000 tons ferronickel containing the grade of $10-12 \% \mathrm{Ni}$ or averagely at $11.74 \% \mathrm{Ni}$. The use of soft coke for the energy at relatively cheap prices is expected to reduce the production costs. Such the energy costs is still the largest part of the overall production cost. The construction cost of 2 furnaces will spend US \$ $29,226,288$ that is used for the development of production facilities, infrastructures and the purchase of machineries and equipment.

The required working capital is US \$ $5,494,893$ that goes for the operational of the smelter plant at the first months of the activities. Such a working capital is needed for starting the production at a $60-\%$ trial and run capacity, with the expectation that the next production can be financed by the result of ferronickel selling. Those included in the operational costs are the purchase cost for compensating the ore at all mining activities, the operating costs of PT MMI, the procurement costs for supporting materials and energy raw materials (Table 2 ). 
Table 2. The working capital for producing the ferronickel using the operational cost for a $60-\%$ early production of USD $5,494,893.00$

\begin{tabular}{lcrr}
\hline \multicolumn{1}{c}{ Item } & $\begin{array}{c}\text { Required raw material } \\
\text { (tons) }\end{array}$ & Price (US\$) & Amount (US\$) \\
\hline Nickel ore & 40,000 & 34.92 & $1,396,800.00$ \\
Coke & 7,200 & 420.63 & $3,028,536.00$ \\
Lime & 3,600 & 50.79 & $182,844.00$ \\
Stone & 1,200 & 10.32 & $12,384.00$ \\
Anthracite & 3,000 & 158.73 & $476,190.00$ \\
Fluorite & 400 & 126.98 & $50,792.00$ \\
\hline \multicolumn{5}{r}{} & Sub Total & 35.70 & $3,750,746.00$ \\
\hline Electricity & 133 & 0.13 & $4,760.00$ \\
Water & 18,000 & 1.07 & $2,340.00$ \\
Fuel and oil & 118,173 & & $126,879.00$ \\
\hline & Sub Total & 28.57 & $133,979.00$ \\
\hline Management cost & 450 & $200,510.57$ & $200,511.00$ \\
Workers Salary & - & & $213,367.00$ \\
\hline Sub Total & & & $5,494,893.00$ \\
\hline TOTAL & & & \\
\hline
\end{tabular}

In 2021, PT. MMI plans to construct 2 lines MBF (2 furnaces) that results in expending the investment cost of US $\$ 28,632,645$. The objective is to improve the production into 108,000 tons Fe-Ni. Thus, the total cost for the project is US\$ $63,632,645$. The sources of funds includes $30 \%$ of equity, $70 \%$ of corporate loans from the bank and other investors. Such the investment cost applies the interest rate of $5.90 \%$ and will uses for clearing the land, planning and developing the factory, civil works and installation construction for the local and imported mechanics, machine and laboratory instrument, constructing waste treatment facilities and building as well as general and administrative costs (Table 3 ). The project life is estimated for 20 years; it means that the ferronickel will begin to be produced in 2017 until 2036 (20 years).

Table 3. The total investment for ferronickel plant

\begin{tabular}{|c|c|c|}
\hline No. & ITEM & $\begin{array}{c}\text { Budget for } 2 \text { Lines } \\
\text { Blast Furnace }\end{array}$ \\
\hline \multirow{11}{*}{1.} & Engineering & US\$ \\
\hline & Reduction Smelting System & \\
\hline & $80 \mathrm{~m}^{3}$ Blast Furnace & $5,714,286$ \\
\hline & Vertical Sintering & $3,682,540$ \\
\hline & Stand Sintering & $3,809,524$ \\
\hline & Lime Kiln & 634,921 \\
\hline & Environmental Production & 761,905 \\
\hline & Sintering refined product warehouse, $1500 \mathrm{~m}^{2}$ & $1,428,571$ \\
\hline & Accessories material warehouse, $600 \mathrm{~m}^{2}$ & - \\
\hline & Raw Material Workshop & $1,142,857$ \\
\hline & Sub Total (1) & $16,031,746$ \\
\hline \multirow{11}{*}{2.} & Auxiliaries for improvement & \\
\hline & Crushing, Screening, MS Equipment & 253,968 \\
\hline & Material Handling & 253,968 \\
\hline & Lab. Sample preparation Equipment & 95,238 \\
\hline & Wire, Cables and Other & 634,921 \\
\hline & Copper sleeve, Engine Oil, Hydraulic Oil & 126,984 \\
\hline & Pump, valves, standard equipment & 190.476 \\
\hline & High \&Low Power Distribution Equipment & 952,381 \\
\hline & Diesel Generator @ 1,500 Kw & $1,587,302$ \\
\hline & Gas Power Generator Equipment @ 3,000 Kw 5,079,365 & $5,079,365$ \\
\hline & Sub Total (2) & $9,174,603$ \\
\hline
\end{tabular}




\begin{tabular}{|c|c|c|}
\hline No. & ITEM & $\begin{array}{c}\text { Budget for } 2 \text { Lines } \\
\text { Blast Furnace }\end{array}$ \\
\hline \multirow{17}{*}{3.} & Others & \\
\hline & Land expenses & 219,072 \\
\hline & Construction management fee & 56,000 \\
\hline & Join commissioning fee & 24,000 \\
\hline & Office and living furniture & 11,000 \\
\hline & Staff training cost & 32,000 \\
\hline & Project management fee & 32,000 \\
\hline & Survey and design & 10,700 \\
\hline & Infrastructure & 153,000 \\
\hline & Heavy equipment for operation & $2,729,167$ \\
\hline & Vehicle for operation & 753,000 \\
\hline & Sub Total (3) & $4,019,930$ \\
\hline & Total Initial Investment Cost $(1)+(2)+(3)$ & $29,226,288$ \\
\hline & Total Investment Cost Year $4^{\text {th }}$ & $28,632,645$ \\
\hline & Project Total Investment Cost & $57,858,933$ \\
\hline & Working Capital & $5,494,893$ \\
\hline & TOTAL INVESMENT & $63,353,826$ \\
\hline
\end{tabular}

The qualified manpower is recruited from either the local or other areas with their technical specifications related to smelter activities. The Palangga smelter plant retains 335 employees for serving two lines
MBF while 4 lines MBF need 555 employees that mostly come from the local area (Table 4). Production activities occurs 3 shifts per day.

Table 4. The quantity and position of the plant employees

\begin{tabular}{|c|c|c|}
\hline Position & Quantity & Class \\
\hline General Manager & 1 & $G$ \\
\hline Staff Functional & 6 & G \\
\hline Safety Officer & 1 & $\mathrm{G}$ \\
\hline Safety Supervisor & 4 & $E$ \\
\hline \multirow[t]{2}{*}{ Environmental Supervisor } & 4 & GE \\
\hline & 16 & \\
\hline \multicolumn{3}{|l|}{ Ore Handling } \\
\hline Manager Ore Handling & 1 & $\mathrm{~F}$ \\
\hline Supervisor & 4 & $E$ \\
\hline Data Treatment \& Logistic & 1 & D \\
\hline Maintenance & 4 & D \\
\hline Ass. Maintenance & 4 & C \\
\hline Screening \& Crushing & 8 & C \\
\hline Screening \& Crushing & 8 & $B$ \\
\hline Control Room of R/D & 4 & C \\
\hline Rotary Dryer & 4 & C \\
\hline Rotary Dryer & 4 & B \\
\hline Screening \& Crushing & 8 & C \\
\hline Screening \& Crushing & 8 & $B$ \\
\hline Mixing House & 4 & C \\
\hline \multirow[t]{2}{*}{ Mixing House } & 4 & $\mathrm{~B}$ \\
\hline & 66 & \\
\hline \multicolumn{3}{|l|}{ Calcining Plant } \\
\hline Manager Calcining Plant & 1 & $\mathrm{~F}$ \\
\hline Supervisor & 4 & $E$ \\
\hline Calcining & 4 & D \\
\hline Dust Treatment & 4 & C \\
\hline Dust Treatment & 4 & B \\
\hline Rotary Kiln & 4 & C \\
\hline Rotary Kiln & 4 & $\mathrm{~B}$ \\
\hline
\end{tabular}

\begin{tabular}{|c|c|c|}
\hline Position & Quantity & Class \\
\hline \multicolumn{3}{|l|}{ Refining Plant } \\
\hline Manager Refining Plant & 1 & $\mathrm{~F}$ \\
\hline Supervisor & 4 & $E$ \\
\hline De-s Operation & 4 & $\mathrm{D}$ \\
\hline De-s Operation & 4 & $\mathrm{C}$ \\
\hline De-s Operation & 8 & B \\
\hline L/D Converter Operation & 4 & C \\
\hline Slag Treatment & 4 & B \\
\hline Overhead Crane & 4 & C \\
\hline Preheating Lodge & 4 & C \\
\hline Brick Work & 4 & B \\
\hline Casting \& Shot Making & 4 & B \\
\hline \multirow{2}{*}{ Ingot and Shot Finishing } & 4 & C \\
\hline & 49 & \\
\hline \multicolumn{3}{|l|}{ Transportation Of Raw \& Slag } \\
\hline Manager Transportation & 1 & $\mathrm{~F}$ \\
\hline Supervisor & 4 & $\mathrm{E}$ \\
\hline Forman & 4 & D \\
\hline Bulldozer Operator & 16 & C \\
\hline Excavator Operator & 4 & C \\
\hline Dump truck Driver & 16 & C \\
\hline Pay Loader Operator & 12 & C \\
\hline Maintenance & 4 & D \\
\hline \multirow[t]{2}{*}{ Ass. Maintenance } & 8 & C \\
\hline & 69 & \\
\hline \multicolumn{3}{|l|}{ Human resources } \\
\hline HR GA Manager & 1 & $\mathrm{~F}$ \\
\hline Administration & 4 & $E$ \\
\hline Logistic & 2 & D \\
\hline Driver & 6 & $\mathrm{~B}$ \\
\hline
\end{tabular}


INDONESIAN MINING JOURNAL Vol. 20, No. 2, October 2017 : 131 - 142

\begin{tabular}{|c|c|c|}
\hline Position & Quantity & Class \\
\hline Control Room & 8 & $\mathrm{C}$ \\
\hline Coal Firing Facility & 4 & C \\
\hline Coal Firing Facility & 4 & B \\
\hline Maintenance & 4 & C \\
\hline \multirow{2}{*}{ Maintenance } & 4 & B \\
\hline & 49 & \\
\hline \multicolumn{3}{|l|}{ Smelting Plant } \\
\hline Supervisor & 4 & $E$ \\
\hline Container Wagon & 4 & C \\
\hline Overhead Crane & 4 & C \\
\hline Control Room or E/F & 4 & C \\
\hline Tapping & 4 & C \\
\hline Cooling System & 4 & $\mathrm{C}$ \\
\hline Maintenance & 4 & $\mathrm{C}$ \\
\hline Maintenance & 8 & $\mathrm{~B}$ \\
\hline
\end{tabular}

The exchange rate of the dollar in October 2016 during the financial feasibility analysis was 1 US $\$=$ IDR 13.100. The production cost for processing nickel ore into ferronickel is US $\$ 81,462,249$ (Table 5). The primary selling at this time is exporting the materials to China with the assumption that the LME price of the ferronickel is US $\$ 1,613$ per ton $\mathrm{Fe}-\mathrm{Ni}$ with the conditions free on board (FOB) condition on the mother vessel. This

\begin{tabular}{lcc}
\hline \multicolumn{1}{c}{ Position } & Quantity & Class \\
\hline Security & 24 & $\mathrm{~B}$ \\
Office Boy & 4 & $\mathrm{~A}$ \\
\hline & 41 & \\
\hline Finance & & \\
Finance Manager & 1 & $\mathrm{~F}$ \\
Finance Administration & 4 & $\mathrm{E}$ \\
Storage & 4 & $\mathrm{D}$ \\
\hline & 9 & \\
\hline & & \\
\hline TOTAL 2 LINES MBF & 335 & \\
\hline TOTAL 4 LINES MBF & 555 & \\
\hline
\end{tabular}

results in the sales revenue is amounted to US $\$ 87,102,000$ at the production rate of 54,000 tons of $\mathrm{Fe}-\mathrm{Ni}$ and the amount of US $\$ 174,204,000$ at the production rate of 108,000 tons of Fe-Ni. Table 5 summarizes the all assumptions above while Table 6 shows the net cash flow of such a company. Calculation of all financial feasibility parameters for PT MMI net cash flow is shown in Table 7 and 8.

Table 5. Summary of assumptions

\begin{tabular}{llr}
\hline No. & \multicolumn{1}{c}{ Objects } & \multicolumn{1}{c}{ Value } \\
\hline 1 & Total Ferronickel production year 1-4 (ton) & 54,000 \\
2 & Total ferronickel production year 5-20 (ton) & 108,000 \\
3 & Ferronickel sale price (US\$/ton) & 1,613 \\
4 & Investment year 1-4 (US\$) & $29,226,288$ \\
5 & Working capital (US\$) & $5,494,893$ \\
6 & Investment year 5-20 (US\$) & $28,632,645$ \\
7 & Production cost (US\$) & $81,462,249$ \\
8 & Age project (year) & 20 \\
9 & Bank interest rates (\%) & 15 \\
10 & Tax profits (\%) & 25 \\
\hline
\end{tabular}

Table 6. Company net cash flows

\begin{tabular}{|c|c|c|c|}
\hline No. & Objects & Unit & Value \\
\hline 1 & Total investment & US\$ & $63,353,826$ \\
\hline \multirow[t]{4}{*}{2} & Benefit (acquired the company from the sale) & & \\
\hline & Year $1-4=54,000$ tons $X 1,613$ & US\$ & $87,102,000$ \\
\hline & Year $5-20=108,000 \times 1,613$ & US\$ & $174,204,000$ \\
\hline & Total Benefit & US\$ & $261,306,000$ \\
\hline 3 & Production cost & US\$ & $81,462,249$ \\
\hline 4 & Income & US\$ & $179,843,751$ \\
\hline \multirow[t]{2}{*}{5} & Tax profits $25 \%$ & US\$ & $44,960,938$ \\
\hline & Net cash flows & US\$ & $134,882.813$ \\
\hline
\end{tabular}


Table 7. Calculation result of financial feasibility study of PT. MMI

\begin{tabular}{clrc}
\hline No. & \multicolumn{1}{c}{ Parameters } & Analysis Results & $\begin{array}{c}\text { Feasible or } \\
\text { not }\end{array}$ \\
\hline 1 & Net Cash Flow (US\$) & $134,882,813$ & Feasible \\
2 & Net Present Value - NPV (US\$) & $726,883,479$ & Feasible \\
3 & Internal Rate of Return - IRR (\%) & 18.00 & Feasible \\
4 & Rate Of Investment - ROI (\%) & 212.90 & Feasible \\
5 & Pay Back Period - PBP (year) & 6.19 & Feasible \\
6 & Benefit Cost Ratio - B/C R (multiple) & 3.21 & Feasible \\
& Break Event Point (BEP) & 754 & Feasible \\
7 & Sale price (US\$) & 50,504 & \\
& Production (Ton) & & \\
\hline
\end{tabular}

Table 8. Calculation result of financial feasibility study of PT. MMI

\begin{tabular}{|c|c|c|c|c|c|c|}
\hline Year & Investment & $\begin{array}{l}\text { Cash flows / } \\
\text { Profit }\end{array}$ & $\begin{array}{c}\text { DF } \\
\text { Bank } \\
15 \% \\
\end{array}$ & $\begin{array}{l}\text { PV Cash flows / } \\
\text { NPV PV Profit }\end{array}$ & $\begin{array}{c}\text { DF PV } \\
18 \%\end{array}$ & $\begin{array}{l}\text { PV Cash flows } \\
\text { NPV PV Profit }\end{array}$ \\
\hline 0 & $63,353,826$ & & & & & \\
\hline 1 & & $71,528,987$ & 0.8695 & $62,194,454$ & 0.84745 & $114,306,440$ \\
\hline 2 & & $134,882,813$ & 0.7561 & $101,984,895$ & 0.71818 & $96,870,139$ \\
\hline 3 & & $134,882,813$ & 0.6575 & $88,685,450$ & 0.60863 & $82,093,726$ \\
\hline 4 & & $134,882,813$ & 0.5717 & $77,112,504$ & 0.51578 & $69,569,857$ \\
\hline 5 & & $134,882,813$ & 0.4971 & $67,050,246$ & 0.43710 & $58,957,278$ \\
\hline 6 & & $134,882,813$ & 0.4323 & $58,309,840$ & 0.37043 & $49,964,640$ \\
\hline 7 & & $134,882,813$ & 0.3759 & $50,702,449$ & 0.31392 & $42,342,413$ \\
\hline 8 & & $134,882,813$ & 0.3269 & $44,093,192$ & 0.26603 & $35,882,875$ \\
\hline 9 & & $134,882,813$ & 0.2842 & $38,333,695$ & 0.22545 & $30,409,330$ \\
\hline 10 & & $134,882,813$ & 0.2471 & $33,329,543$ & 0.19106 & $25,770,710$ \\
\hline 11 & & $134,882,813$ & 0.2149 & $28,986,317$ & 0.16191 & $21,838,876$ \\
\hline 12 & & $134,882,813$ & 0.1869 & $25,209,598$ & 0.13721 & $18,507,271$ \\
\hline 13 & & $134,882,813$ & 0.1625 & $21,918,457$ & 0.11628 & $15,684,173$ \\
\hline 14 & & $134,882,813$ & 0.1413 & $19,058,941$ & 0.09854 & $13,291,352$ \\
\hline 15 & & $134,882,813$ & 0.1228 & $16,563,609$ & 0.08510 & $11,478,527$ \\
\hline 16 & & $134,882,813$ & 0.1068 & $14,405,484$ & 0.07077 & $9,545,657$ \\
\hline 17 & & $134,882,813$ & 0.0929 & $12,530,613$ & 0.06997 & $9,437,750$ \\
\hline 18 & & $134,882,813$ & 0.0808 & $10,898,531$ & 0.05083 & $6,856,093$ \\
\hline 19 & & $134,882,813$ & 0.0702 & $9,468,773$ & 0.05307 & $7,158,231$ \\
\hline 20 & & $134,882,813$ & 0.0611 & $8,241,340$ & 0.04650 & $6,272,051$ \\
\hline \multicolumn{2}{|c|}{$\begin{array}{l}\text { Total PV cash flows } \\
\text { for } 20 \text { years }\end{array}$} & & 6.1974 & $726,883,479$ & 5.3842 & $726,237,391$ \\
\hline
\end{tabular}

Using the same measurement variables with the financial analysis of PT. MMI for analyzing the business sensitivity, namely the selling price of ferro-nickel (Fe-Ni) is assumed to be downgraded to 5\% (Table 9) and the production costs is increased to $5 \%$ (Table 10), the plan for constructing smelter plant is not sensitive to the decrease of selling prices and the increase of production costs. By both the sensitivity calculation of nickel laterite smelter plant into ferronickel, it is going to be commercialized by PT.MMI although the sale price is lowered by $5 \%$ or the cost of production increased by $5 \%$. It is still well worth to run.

Table 9 . Financial feasibility analysis for PT. MMI if the selling price is decreased by $5 \%$.

\begin{tabular}{llrc}
\hline No. & \multicolumn{1}{c}{ Parameters } & Analysis results & Feasible or not \\
\hline 1 & Net Cash Flow (US\$) & $125,041,313$ & Feasible \\
2 & Net Present Value - NPV (US\$) & $673,847,637$ & Feasible \\
3 & Internal Rate of Return - IRR (\%) & 18.00 & Feasible \\
4 & Rate of Investment - ROI (\%) & 197.37 & Feasible \\
\hline
\end{tabular}




\begin{tabular}{llrc}
\hline No. & \multicolumn{1}{c}{ Parameters } & Analysis results & Feasible or not \\
\hline 5 & Pay Back Period - PBP (year) & 6.19 & Feasible \\
6 & Benefit Cost Ratio - B/C R (multiple) & 3.05 & Feasible \\
7 & Break Event Point (BEP) & & Feasible \\
& Sale price (US\$) & 754 & \\
& Production (Ton) & 53,174 & \\
\hline
\end{tabular}

Table 10. Financial feasibility analysis for PT. MMI if production cost is increased by $5 \%$.

\begin{tabular}{clrc}
\hline No. & \multicolumn{1}{c}{ Parameters } & Analysis results & Feasible or not \\
\hline 1 & Net Cash Flow (US\$) & $131,827,979$ & Feasible \\
2 & Net Present Value - NPV (US\$) & $710,420,980$ & Feasible \\
3 & Internal Rate of Return - IRR (\%) & 18.00 & Feasible \\
4 & Rate of Investment - ROI (\%) & 208.08 & Feasible \\
5 & Pay Back Period - PBP (year) & 6.19 & Feasible \\
6 & Benefit Cost Ratio - B/C R (multiple) & 3.05 & Feasible \\
7 & Break Event Point (BEP) & 792 & Feasible \\
& Sale price (US\$) & 53,029 & \\
& Production (Ton) & & \\
\hline
\end{tabular}

\section{CONCLUSIONS}

The ferronickel smelting plant of PT. Macika Mineral Industries is feasible to be built. Economic evolution using project evaluation method with the assumption of $15 \%$ interest rate and project life of 20 years shows that:

- the obtained net cash flow is US \$ $134,882,813$. Such an amount is higher than that of the production cost incurred by the company;

- a positive net cash flow of US \$ $726,883,479$ is obtained at NPV of $15 \%$ DF;

- an $18-\%$ DCF ROR/IRR is obtained from $30-\%$ equity financing and 70 $\%$ loan capital. The loan capital is higher than the $15-\%$ DF;

- PBP of 6.19 years results in the investment return of the profits is faster than that of the 20-year project life;

- the minimum $15 \%$ or BEP on DCF ROR/IRR occurs at the fixed selling price and result in the condition of BEP production levels around 50.504 tons, while the selling price of BEP is US $\$ 754$ / ton.

The sensitivity calculation when the sale price is lowered by $5 \%$ show that the company is still worth to be developed. The economic calculations using the project evaluation method and the assumption of sale price lowered by $5 \%$ is as follows:

a. the obtained net cash flow is US \$ $125,041,313$. This number is higher than that of the production cost; b. the NPV at $15 \%$ DF provided a positive net cash flow around US\$ $673,847,637$;

c. the $30-\%$ equity and the $70-\%$ loan capital yield $18 \%$ of DCF ROR/IRR. Such a figure is higher than that of the $15-\%$ expected DCF;

d. the PBP is 6.19 years to get faster the investment return from the achieved profits than the 20-year project life.

e. the minimum $15 \%$ BEP on DCF ROR / IRR occurs when the selling price is fixed, the BEP condition at sale production level is 53,174 tons, while the BEP selling price is US\$ 754.00 / ton.

Raising the production cost to $5 \%$ shows that, the company is still worth to be implemented. It indicates that:

a. the obtained net cash flow is US\$ $131,827,979$. Such a figure is higher than that of the production cost;

b. the positive net cash flow of US \$ $710,420,980$ is obtained at NPV of $15-\%$ DF;

G. the $30-\%$ equity and the $70-\%$ loan capital yield $18 \%$ of DCF ROR/IRR. Such a figure is higher than that of the $15-\%$ expected DCF;

d. the PBP is 6.19 years to get faster the investment return from get faster profits than from the achieved the project's life 20-year;

e. the minimum 15-\% BEP on DCF ROR / IRR occurs when the selling 
price is fixed, then the BEP condition is suggest production level is 53,029 tons, while the BEP selling price is US\$ 792.00 / ton.

\section{SUGGESTIONS}

1. PT. MMI is suggested to cooperate with the local entrepreneurs in South Konawe in conducting the project. The objective is to transfer the technology in the mining sector, to open a job opportunity for the local community, to follow the standard procedure for controlling and managing the environment around the mine, so the presence of PT. MMI will benefit not only for the company, but also for South Konawe society.

2. The company should manage the wastes from its activity wisely to avoid the negative environmental impact. As a result, the company should continuously monitor any changes of the environment either, physical, chemical, biological and socio-economic culture.

3. The local governments should support the company activities by building the necessary infrastructure such as electric energy, roads, bridges ports, and various regional regulation as well as the ease of getting permit to facilitate and accelerate the smelting phase of nickel ore during milling operations commence.

\section{ACKNOWLEDGEMENT}

The authors would like to thank the entire Board of Directors of PT. Macika Mineral Industries, Department of Mines and Energy of Southeast Sulawesi, the Regional Planning Agency of Southeast Sulawesi, the Central Bureau of Statistics of Southeast Sulawesi for their assistance to provide data and information

\section{REFERENCES}

Afandi, P. (2014) "Analisis kelayakan usaha unit pemecah batu dengan pendekatan 'capital budgeting' pada CV Eka Mandiri Randu Acir Salatiga," Jurnal STIE Semarang, 6(1), pp. 1-17. Available at: http://download.portalgaruda.org/article. php?article $=200101 \&$ val $=6603 \&$ title $=A$ NALISIS KELAYAKAN USAHA UNIT PEMECAH BATU DENGAN PENDAKATAN BUDGETINGâ€ PADA CV EKA MANDIRI RANDU ACIR SALATIGA.

Astuti, W., Zulhan, Z., Shofi, A., Isnugroho, K., Nurjaman, F. and Prasetyo, E. (2012) "Pembuatan Nickel Pig Iron (NPI) Dari Bijih Nikel Laterit Indonesia Menggunakan Mini Blast Furnace," in Seminar Insentif Riset SINas. Jakarta: Asdep Relevansi Program Riptek, p. MT66-MT71. Available at: http://biofarmaka.ipb.ac.id/biofarmaka/2 013/PIRS 2012 - file-MT-TeX_11.pdf.

Badan Pusat Statistik Provinsi Sulawesi Tenggara (2014) Sulawesi Tenggara Dalam Angka 2014. Kendari. Available at: https://www.scribd.com/doc/275895238 /Sulawesi-Tenggara-Dalam-Angka2014.

Baroto and Ariani, K. T. (2010) "Analisa kelayakan usaha pengolahan ubi kayu menjadi selondok Desa Banjariarjo, Kecamatan Kalibawang, Kabupaten Kulon Progo," Jurnal IImu-ilmu Pertanian, 6(1), pp. 69-78.

Dinas Pertambangan Provinsi Sulawesi Tenggara (2015) Pertambangan Propinsi Sulawesi Tenggara. Kendari.

Ermiati (2011) "Analisa kelayakan, kendala pengembangan usahatani dan solusi diversifikasi produk akhir temulawak di Kabupaten Bogor (studi kasus Kecamatan Cileungsi)," Buletin Penelitian Tanaman Rempah dan Obat, 22(1), pp. 97-114. doi: 10.21082/bullittro.v22n1.2011.\%25p.

Fahmi, I. (2011) Analisis laporan keuangan. Bandung: CV. Alfabeta.

Haryadi, H. (2013) "Analisis kelayakan finansial pembangunan pabrik sga (smelter grade alumina) Mempawah dengan proses Bayer," Jurnal Teknologi Mineral dan Batubara, 9(2), pp. 74-87.

Haryadi, H. (2016) "Dampak pembangunan smelter nikel terhadap perekonomian daerah Provinsi Sulawesi Tenggara," Buletin Sumber Daya Geologi, 11(1), pp. 25-39. Available at: http://buletinsdg.geologi.esdm.go.id/ind ex.php/bsdg/article/view/BSDG Vol 11 No Artikel 3/pdf. 
Honesti, L. and Djali, N. (2012) "Analisis ekonomi dan finansial pengembangan bandar udara internasional Minangkabau (BIM) di Sumatera Barat," Jurnal Momentum, 13(2), pp. 50-59. Available

at: https://ejournal.itp.ac.id/index.php/mom entum/article/view/41/38.

Kartaman, M., Al Hasa, M. H. and Paid, A. (2013) "Pengaruh temperatur terhadap sifat bahan paduan alumunium fero nikel," Jurnal Urania, 19(2), pp. 109118.

doi:

10.17146/urania.2013.19.2.1785.

Kementerian Perdagangan (2013) Perdagangan ekspor dan impor Indonesia. Jakarta.

Khumairoh, N. S. (2013) "Analisa investasi dengan feasibility study untuk meningkatkan kecerdasan finansial pada budi daya ikan di Sidoarjo," DiE Jurnal IImu Ekonomi dan Manajemen, 9(2), pp. 184-193. Available at: http://jurnal.untag-

sby.ac.id/index.php/die/article/view/215/ 56

Musnajam (2012) "Optimalisasi pemanfaatan bijih nikel kadar rendah dengan metode blending di PT. ANTAM Tbk. UBPN Sulawesi Tenggara," Jurnal Teknologi Technoscientia, 4(2), pp. 213-222. Available

at: http://technoscientia.akprind.ac.id/techn o/files/full/vol4no2feb2012/Musnajam_2 13-222.pdf.
Permana, D. (2010) "Dampak penerapan Undang-Undang No. 4 Tahun 2009 tentang pengembangan usaha pertambangan mineral dan batubara," urnal Teknologi Mineral dan Batubara, 6(4), pp. 165-173.

Pratama, B. E., Sibarani, D. and Puspandaru, A. (2011) Ekstraksi nikel dari bijih nikel laterit melalui proses pelindian dengan memanfaatkan bakteri. Institut Teknologi Bandung. Available at: http://pkm.mfkasim.com/files_upload/P KM-GT.pdf-120115133956.pdf.

Pusat Sumber Daya Geologi (2014) Laporan akhir pemutakhiran data dan neraca sumber daya mineral. Bandung.

Rusdiana, S. and Martono, B. (2014) "Analisis finansial diversifikasi usaha perkebunan kakao rakyat dan ternak kambing di tingkat petani," Jurnal SIRINOV, 2(3), pp. 157-170. Available at: file://C:/Users/Bachtiar/AppData/Local/ Temp/2. analisis finansial diversifikasi usaha perkebunan.pdf.

Subagja, R., Prasetyo, A. B. and Mayangsari, W. (2016) "Peningkatan kadar nikel dalam laterit jenis limonit dengan cara peletisasi, pemanggangan reduksi dan pemisahan magnet campuran bijih, dan Na2SO4," Jurnal Metalurgi, 31(2), pp. 103-115. doi: 10.14203/mtl.v31i2.171. 